University of Nebraska - Lincoln

DigitalCommons@University of Nebraska - Lincoln

Papers in the Earth and Atmospheric Sciences

Earth and Atmospheric Sciences, Department

\title{
Berino Paleosol, Late Pleistocene Argillic Soil Development on the Mescalero Sand Sheet in New Mexico
}

\author{
Stephen A. Hall \\ Red Rock Geological Enterprises, Santa Fe, NM, redrock2@comcast.net \\ Ronald J. Goble \\ University of Nebraska-Lincoln, rgoble2@unl.edu
}

Follow this and additional works at: https://digitalcommons.unl.edu/geosciencefacpub

Part of the Earth Sciences Commons

Hall, Stephen A. and Goble, Ronald J., "Berino Paleosol, Late Pleistocene Argillic Soil Development on the Mescalero Sand Sheet in New Mexico" (2012). Papers in the Earth and Atmospheric Sciences. 325. https://digitalcommons.unl.edu/geosciencefacpub/325

This Article is brought to you for free and open access by the Earth and Atmospheric Sciences, Department of at DigitalCommons@University of Nebraska - Lincoln. It has been accepted for inclusion in Papers in the Earth and Atmospheric Sciences by an authorized administrator of DigitalCommons@University of Nebraska - Lincoln. 


\title{
Berino Paleosol, Late Pleistocene Argillic Soil Development on the Mescalero Sand Sheet in New Mexico
}

\author{
Stephen A. Hal1 ${ }^{1, \star}$ and Ronald J. Goble ${ }^{2}$ \\ 1. Red Rock Geological Enterprises, 3 Cagua Road, Santa Fe, New Mexico 87508, U.S.A.; 2. Department of Earth \\ and Atmospheric Sciences, 214 Bessey Hall, University of Nebraska, Lincoln, Nebraska 68588, U.S.A.
}

\begin{abstract}
A B S T R A C T
The Berino paleosol is the first record of a directly dated Aridisol in the American Southwest where paleoclimatic conditions during the time of pedogenesis can be estimated. The noncalcic, argillic paleosol formed in eolian sand during the cool, wet climate of the mid- and late Wisconsin, marine isotope stages 3 and 2, in presently semiarid southeastern New Mexico. Optically stimulated luminescence dating of the Mescalero sand sheet and the Berino indicates that soil formation occurred during the period 50-18 ka. The paleosol is a red 2.5YR hue Bt horizon, 120 $\mathrm{cm}$ thick, with $25 \%$ clay, $0.36 \% \mathrm{Fe}$, and an absence of visible carbonate. It is buried by younger eolian sand, although at the edges of the sand sheet, it is unburied and a relict soil. Red argillic paleosols in other sand sheets in the region may correlate with the Berino. The Berino paleosol is formally named as a pedostratigraphic unit.
\end{abstract}

\section{Introduction}

Calcic paleosols and calcretes are common in arid and semiarid landscapes in the American Southwest. A great deal of attention has been given to equating stages of carbonate morphology with time and using calcic paleosols as a means of relative dating of geologic deposits and geomorphic surfaces (Gile et al. 1981; Weide 1985). Noncalcic argillic paleosols in dry lands, however, are less conspicuous and, accordingly, less well known. The Berino paleosol of southeastern New Mexico is a prominent example of late Pleistocene argillic soil development, and the geochronology and paleoenvironment of its formation are presented in this article.

The Mescalero Plain in southeastern New Mexico is a gently undulating surface of eroded Permian and Triassic redbeds extending from the western edge of the High Plains caprock escarpment to the breaks of the Pecos River (Bretz and Horberg 1949; Hendrickson and Jones 1952; Nicholson and Clebsch 1961; Kelley 1971). Fluvial deposits of the Gatuña Formation (middle Pleistocene) occur in small areas over the plain (Bachman 1976). The 2011.

Manuscript received May 16, 2011; accepted November 16,

* Author for correspondence; e-mail: redrock2@comcast.net.
Mescalero paleosol with stage III carbonate morphology occurs throughout the plain on the eroded surface of Permian-Triassic-Pleistocene rocks, and the resistance to erosion of the paleosol promotes the formation of low escarpments (Bachman 1976, 1980). The surface of the plain, especially the eastern half, is mantled by wind-deposited sand of the Mescalero sand sheet (Peterson and Boyd 1998; Hall 2002; Hall and Goble 2006, 2008, 2011; fig. 1). The sand sheet extends north from Texas across the Mescalero Plain to the northern part of Chaves County, New Mexico, and includes areas of active dunes called the Mescalero Sands and Los Medaños. Other small patches of presently active dunes occur across the sand sheet. Isolated deposits of eolian sand are also located in the transition area between the core of the Mescalero sand sheet of New Mexico and the Monahans sand sheet of Texas. The relationship of these isolated deposits to the sand sheets is not yet determined.

\section{Methods}

The Berino paleosol is poorly exposed in the field, and the three study localities discussed here were excavated with a backhoe to uncover the paleosol and associated stratigraphy. Soil samples were col- 


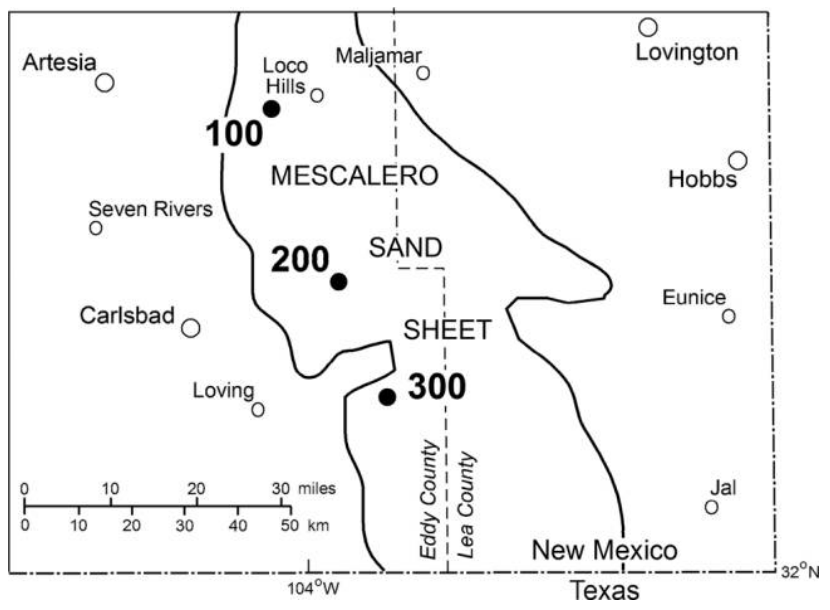

Figure 1. Map of southeastern corner of New Mexico with optically stimulated luminescence-dated localities (100-300) of the Lower eolian sand and the Berino paleosol. The sand sheet includes patches of Permian and Triassic rocks where the eolian sand has been removed by erosion or was never deposited. Areas of eolian sand occur east of the sand sheet, but their relationship to the Mescalero (New Mexico) and Monahans (Texas) sand sheets is not well established.

lected every $10 \mathrm{~cm}$ from the entire stratigraphic sections, including the Berino paleosol, and the textural and chemical analyses were conducted by the Milwaukee Soil Laboratory. The Wentworth scale was used for sand, silt, and clay categories (Folk 1968); the sand fractions were determined by sieves, and the silt-clay fractions were determined by hydrometer. The Wentworth scale is commonly applied to sedimentology and differs from the particle size categories used in engineering and soil science. Accordingly, the percentages of very fine sand, silt, and clay in this investigation may not be directly comparable with those of studies where other size categories are reported. Carbonate percentages were determined by the chittick method and the Fe percentages by the citrate-dithionite method. Organic carbon was determined by the Walkley-Black method, but the percentages are too small to be significant and are not reported here. The percentages of very coarse and coarse sand are negligible and are not shown in the sediment diagrams. The sediment diagrams focus on the Berino paleosol and do not include data from the overlying postpaleosol mantle. Soil terms are from Soil Survey Staff (1994) and Birkeland (1999); sediment and soil colors are from Munsell (2009).

\section{Optically Stimulated Luminescence (OSL) Dating}

OSL Sample Preparation/Dose Rate Determination. Sample preparation was carried out under amber-light conditions. Samples were wet sieved to extract the 90-150- $\mu \mathrm{m}$ fraction and then treated with $\mathrm{HCl}$ to remove carbonates. Quartz and feldspar grains were extracted by flotation using a 2.7 $\mathrm{g} \mathrm{cm}^{3}$ sodium polytungstate solution and then treated for $75 \mathrm{~min}$ in $48 \% \mathrm{HF}$, followed by $30 \mathrm{~min}$ in $47 \% \mathrm{HCl}$. Reddish sands with heavy iron oxide coatings were given an additional treatment with CBD solution (sodium citrate, sodium bicarbonate, sodium dithionate). The samples were then resieved, and the $<90-\mu \mathrm{m}$ fraction was discarded to remove residual feldspar grains. The etched quartz grains were mounted on the innermost 2 or $5 \mathrm{~mm}$ of 1-cm aluminum disks using Silkospray.

Chemical analysis for $\mathrm{U}, \mathrm{Th}$, and $\mathrm{K}$ was carried out by Chemex Labs (Sparks, NV), using a combination of ICP-MS and ICP-AES. Dose rates were calculated using the method of Aitken (1998) and Adamiec and Aitken (1998). The cosmic contribution to the dose rate was determined using the techniques of Prescott and Hutton (1994).

Optical Measurements. Optically stimulated luminescence analyses were carried out on a Riso automated OSL dating system (model TL/OSL-DA15B/C), equipped with blue and infrared diodes, using the single aliquot regenerative dose technique (Murray and Wintle 2000). All equivalent dose $\left(D_{\mathrm{e}}\right)$ values were determined using the central age model (Galbraith et al. 1999); data analysis showed no evidence of partial bleaching (Bailey and Arnold 2006). Preheat and cutheat temperatures were based on preheat plateau tests between $180^{\circ}$ and $280^{\circ} \mathrm{C}$, which indicated that a $240^{\circ} \mathrm{C} / 10$ s preheat and $220^{\circ} \mathrm{C} / 0 \mathrm{~s}$ cutheat were appropriate. Dose recovery and thermal transfer tests were conducted (Murray and Wintle 2003). Growth curves were examined to determine whether the samples have $D_{\mathrm{e}}$ values $<2 D_{\mathrm{o}}$, the value at which the OSL signal is about $15 \%$ below the level where the dose response curve flattens at saturation (Wintle and Murray $2006) ; D_{\mathrm{o}}$ is determined from the saturating exponential equation. Optical ages were based on a minimum of 50 accepted aliquots (Rodnight 2008). Individual aliquots were monitored for insufficient count rate, poor-quality fits (i.e., large error in $D_{\mathrm{e}}$ ), poor recycling ratio, strong medium versus fast component, and detectable feldspar. Aliquots deemed unacceptable based on these criteria were discarded from the data set before averaging. Averaging was carried out using the central age model (Galbraith et al. 1999) rather than the minimum age model (Galbraith et al. 1999), based on the $D_{\mathrm{e}}$ distribution (symmetric distribution; skewness $<2 \sigma_{\text {ci }}$ Bailey and Arnold 2006).

OSL Dating and Climate Change. We conclude 
(see below) that the Berino paleosol formed under climatic conditions in the late Pleistocene that were cooler and wetter than at present. Increased rainfall likely resulted in elevated soil moisture that would in turn lower the historic dose rate and thus increase the calculated optical age. As a check, we increased the moisture content of UNL 1995 from $2.3 \%$ to $8.0 \%$. The calculated age increased from $59.1 \pm 3.5$ to $63.0 \pm 3.8 \mathrm{ka}$, just above the $1 \sigma$ but well within the $2 \sigma$ error. These results indicate that elevated soil moisture in the past may not have a statistically significant influence on the OSL ages from the Mescalero sand sheet.

Laboratory data and OSL ages from localities 100 and 200 are given by Hall and Goble (2011); the OSL ages from locality 100 were revised slightly from those reported in an earlier article (Hall and Goble 2006). The laboratory data from locality 300 have not been previously published and are given in table 1.

\section{Berino Paleosol: Definition}

The Berino paleosol is defined in this article as the noncalcic, argillic soil in the Mescalero sand sheet of southeastern New Mexico. The Berino is an Aridisol with an argillic but lacking a calcic or petrocalcic horizon and thus is classified as an Argid (Soil Survey Staff 1994). Even though a pedostratigraphic unit can be developed in one or more stratigraphic units, the Berino paleosol is observed only in the Lower eolian sand of the sand sheet. The Berino is called a paleosol, a term in current use in North America for any soil that formed on a landscape of the past (North American Commission on Stratigraphic Nomenclature 2005, p. 1559). In most cases, the Berino paleosol overlies the calcic Mescalero paleosol, forming a sharp contact with the caliche. The Berino paleosol is buried by younger eolian sand in the core area of the sand sheet. It also occurs commonly at the present surface of the sand sheet, especially in the western margin, where it is unburied and a relict soil (Ruhe 1965).

The term "Berino" appears in county soil surveys as the Berino series in southern New Mexico and adjacent Texas (Chugg et al. 1971; Jaco 1971; Turner et al. 1974; Neher and Bailey 1976; Bulloch and Neher 1980; Derr 1981). It takes its name from a small unincorporated community called Berino located a few miles north of Anthony, near the TexasNew Mexico state line in the Rio Grande valley. The Berino series is generally described in the county soil surveys, cited above, as a sandy argillic soil. Bachman (1980, 1981, 1984) first used the term "Berino soil" as an informal stratigraphic unit while mapping the surface geology of southeastern New Mexico in the 1970s. Based on the absence of carbonate in its B horizon, he concluded that it must have formed in the Pleistocene under conditions that were wetter than at present, the carbonates being leached. In defining the paleosol, we use the term "Berino paleosol," following the precedent set by Bachman (1980), who recognized "Berino soil" as a stratigraphic unit in the Pleistocene sequence of the region.

The type section of the Berino paleosol is located on state land in a sand pit along the west side of Valley Gas Road, $1.3 \mathrm{~km}(0.8 \mathrm{mi})$ south of U.S. Highway 82, west of the community of Loco Hills, Eddy County. The locality is locality 1 in Hall (2002), VG (Valley Gas Road) in Hall and Goble (2006, 2011), and locality 100 in this article. The sand pit should provide a lasting and easy-to-clean exposure of the Berino paleosol; localities 200 and 300 are soil pits that are now filled in.

\section{Characterization}

The Berino paleosol is best observed at the type locality where the entire Bt horizon is exposed (fig. 2). The Bt horizon is generally $100-120 \mathrm{~cm}$ thick. The A horizon is not preserved, removed by erosion. The top part of the Bt horizon may also have been removed by erosion in some areas of the sand sheet. The color of the Bt horizon is commonly red (2.5YR 4/6). The Bt horizon has a maximum clay content ranging from $17 \%$ to $25 \%$, and the maximum amount of $\mathrm{Fe}$ is $0.36 \%$ (fig. 3). At the type section, clay films on sand grains and pore surfaces are absent to very few, although grains are entirely coated by Fe. In other sections of the Berino paleosol across the sand sheet, clay films on grains are few to many. The Bt has a very weak to absent ped structure. The Bt is soft to slightly hard and nonsticky and nonplastic when wet. Cylindrical cicada insect burrows $10-20 \mathrm{~m}$ in diameter filled with red sand are present in the upper Bt at many localities. Carbonate coats, carbonate filaments, and nodules are absent, and the Bt sediment does not effervesce in dilute $\mathrm{HCl}$, although laboratory data show carbonate ranging from $0.9 \%$ to $3.5 \%$ in the Bt horizon. Btk and Bk horizons are absent everywhere. The base of the B horizon is diffuse at the type section, although in profiles where the parent sand is thin, the base of the Bt horizon forms an abrupt, sharp boundary with the underlying caliche of the Mescalero paleosol. In the C horizon below $120 \mathrm{~cm}$ depth at the type locality, small amounts of carbonate are visible as weak cement around rootlet pores and faint coats on some sand grains, occurring 


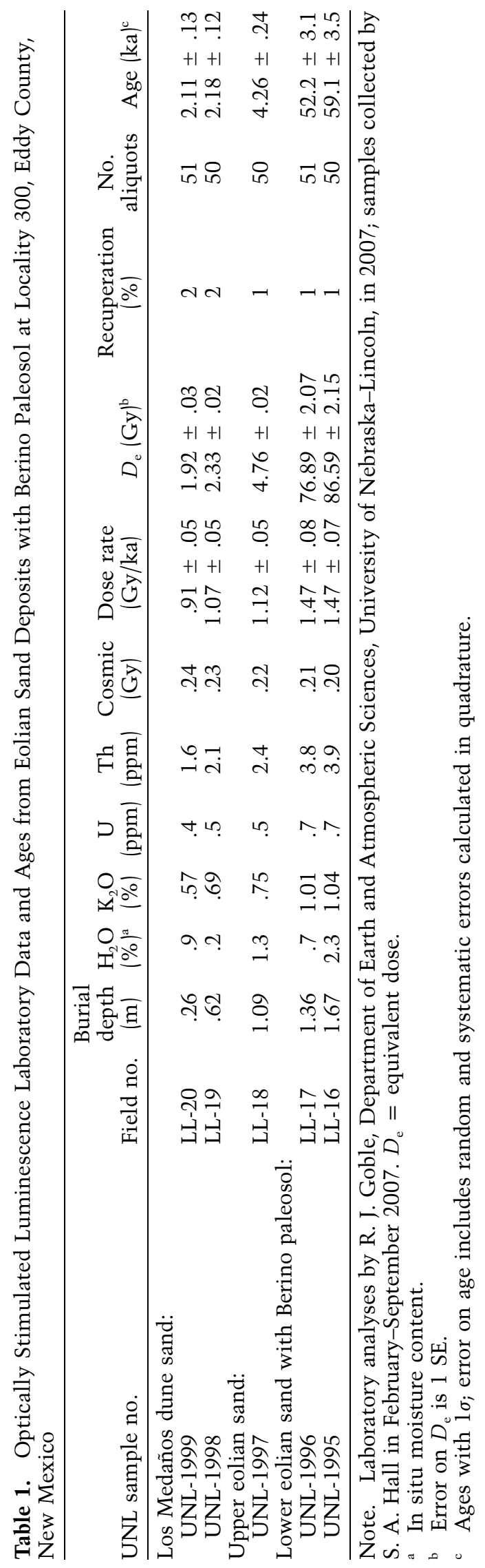




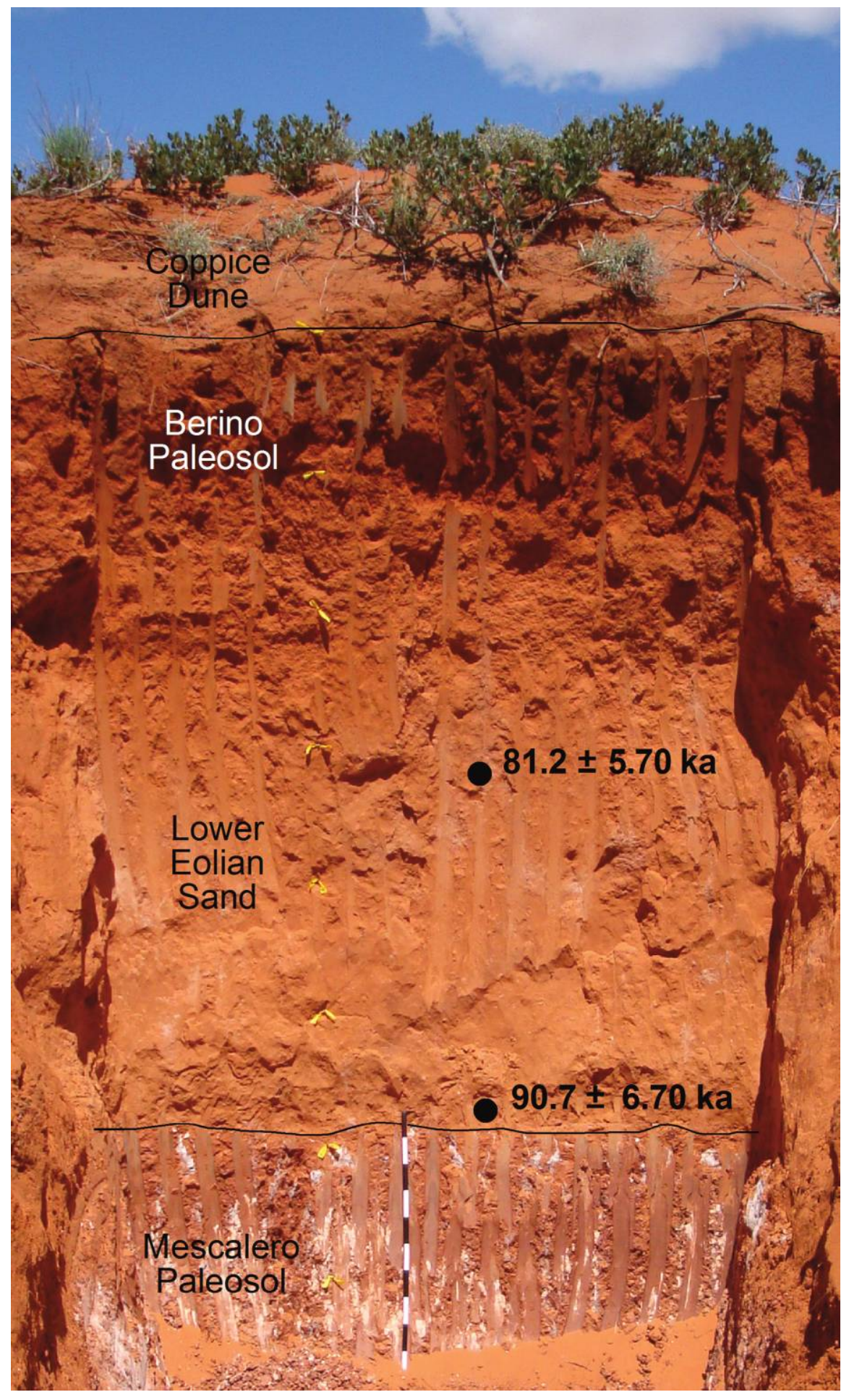

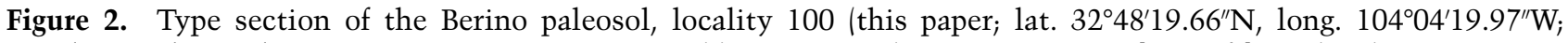
NE1/4 NE1/4 SE1/4 sec. 28, T. 17 S., R. 29 E., Eddy County; elevation, 1086 m [3562 ft]; Red Lake SE 7.5-min quadrangle, USGS 1955). The stratigraphic position of the two optically stimulated luminescence (OSL) ages in the measured section are shown. These OSL ages are revised in Hall and Goble (2011) and are slightly different from the OSL ages reported earlier from this section by Hall and Goble $(2006,2008)$. The yellow tags in the measured section are at $50-\mathrm{cm}$ intervals. The coppice dune at the top of the section accumulated during the twentieth century. The exposure is at the north edge of the sand pit (1-m scale). Photograph taken May 3, 2010, at 11:28 a.m. 

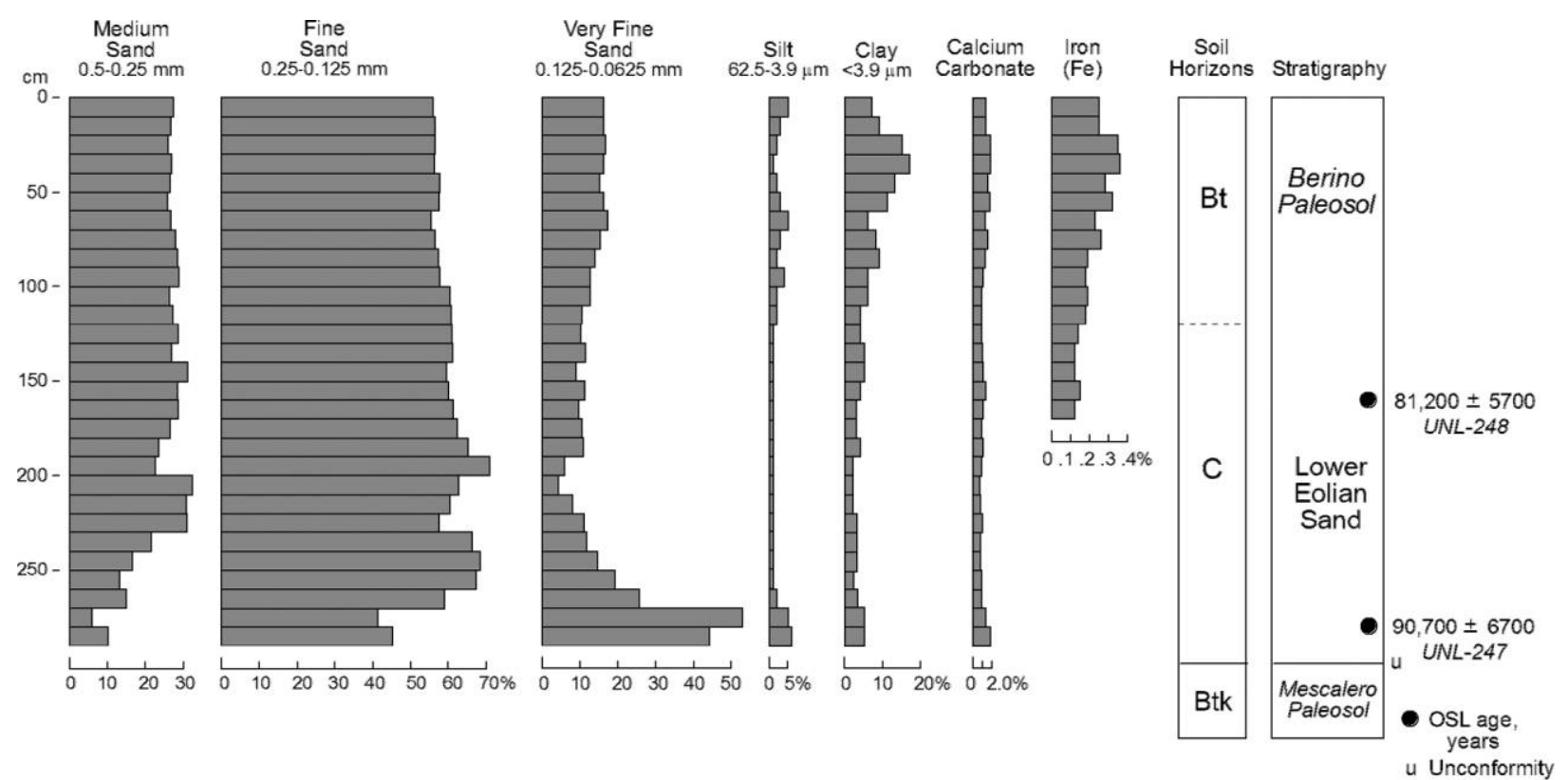

Figure 3. Sedimentology and chemistry of the Lower eolian sand and type section of the Berino paleosol, locality 100, Eddy County, New Mexico; locality information given with figure 2. The change in texture and chemistry in the lower $20-30 \mathrm{~cm}$ at the base of the section is a result of local redeposition of calcareous sand-silt-clay derived from deflation of the underlying Btk horizon of the Mescalero paleosol.

as small, isolated patches of whitening in the sand. The sand is slightly effervescent in dilute HCl. Laboratory analysis shows that the amount of carbonate in the $\mathrm{C}$ horizon is small, ranging from $0.8 \%$ to $1.4 \%$. Many sand grains throughout the $\mathrm{C}$ horizon have Fe coats; the amount of Fe ranges from $0.12 \%$ to $0.15 \%$, giving the sand a red color $(2.5 \mathrm{YR}$ $5 / 6 \mid$, although not as red as the Bt horizon.

\section{Parent Material}

The Berino paleosol occurs throughout the Mescalero sand sheet at the top of the Lower eolian sand, the parent material of the paleosol. The Lower eolian sand is the older of the two main eolian sand units that make up the Mescalero sand sheet. It is a well-sorted, massive, fine- to mediumand fine- to very fine-textured quartz sand with less than $5 \%$ silt and less than $5 \%$ clay. The sand grains are subrounded to subangular and commonly have Fe coats, probably due to the presence of the Berino paleosol. The sand is soft. The thickness of the Lower eolian sand varies from 40 to $300 \mathrm{~cm}$ and overlies weathered, eroded caliche of the Mescalero paleosol. In many cases, the top of the Berino paleosol is truncated, indicating that erosion of the Lower eolian sand occurred after paleosol formation (figs. 4, 5). In many areas of the sand sheet, the Lower sand is missing entirely, perhaps due to non- deposition. Where the Lower eolian sand is missing, the Berino paleosol is not present, and the Upper eolian sand rests directly on the Mescalero paleosol.

The $25 \%$ clay in the Berino is probably derived from the influx of atmospheric dust and the translocation of the clay component downprofile where it accumulated, forming the argillic horizon. The predominant wind direction in this region is from the west and southwest. Upwind and west of the Mescalero sand sheet, a series of atmospheric sediment traps were monitored between 1962 and 1972 in the Rio Grande Valley near Las Cruces, New Mexico (Gile et al. 1981, p. 63-65). Average annual silicate clay deposition in the traps ranged from $13 \%$ to $39 \%$. The average annual amount of silt ranged from $17 \%$ to $45 \%$; the remainder of the trapped particles was mostly very fine to fine sand. Other studies document as well the ubiquitous presence of atmospheric dust throughout region (Stout and Lee 2003; Reheis 2006).

\section{Geochronology of Parent Material}

The age of the Lower eolian sand has been determined by OSL dating. Six OSL ages range from $90.7 \pm 6.7$ to $52.2 \pm 3.1 \mathrm{ka}$ (Hall and Goble 2006, 2011; this article); the age rounded to $90-50 \mathrm{ka}$. The period of deposition of the Lower eolian sand cor- 

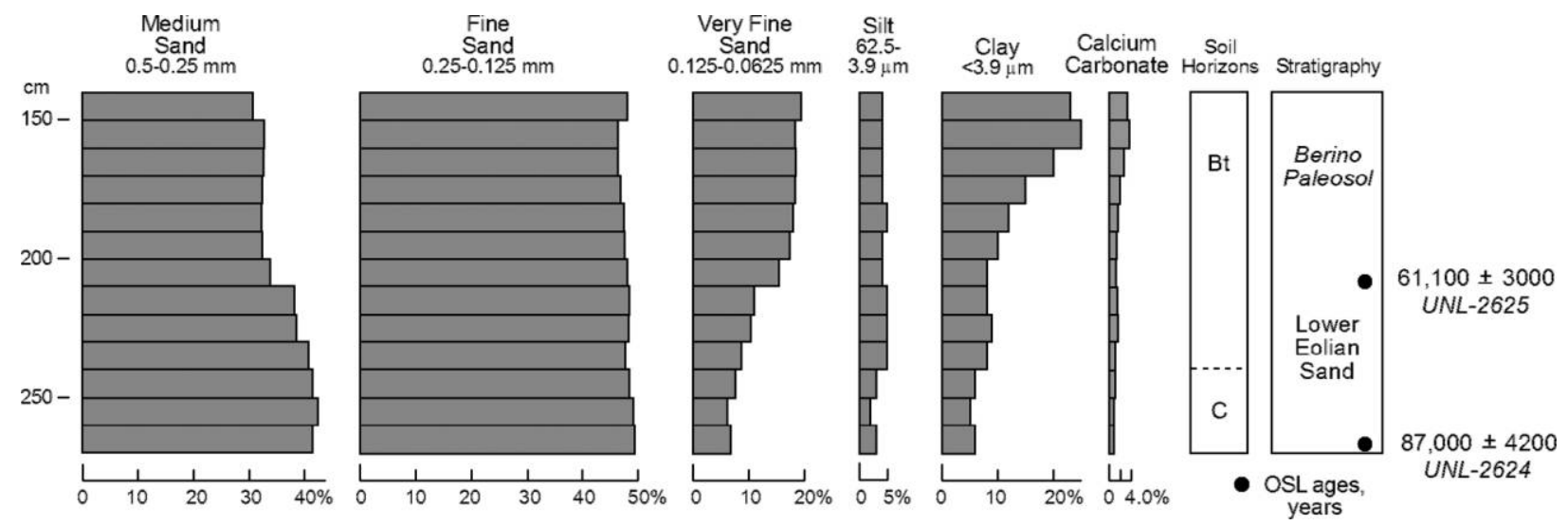

Figure 4. Sedimentology and chemistry of the Lower eolian sand and Berino paleosol, locality 200 (lat. $32^{\circ} 30^{\prime} 47.9^{\prime \prime} \mathrm{N}$,

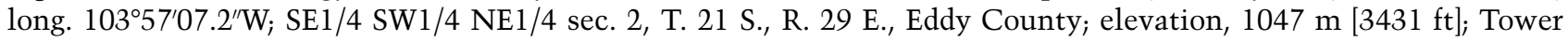
Hill North, provisional edition, 7.5-min quadrangle, USGS 1985). The high percentages of clay and carbonate at the upper level of the profile suggest that the top of the Bt horizon has been truncated by erosion.

relates with the late "Eowisconsin," early Wisconsin, and early mid-Wisconsin glacial stages and marine isotope stages (MIS) 5A, 4, and early 3 (Richmond and Fullerton 1986). It should be noted that a uranium age of the Berino paleosol, now known to be inaccurate based on OSL dating (Hall and Goble 2006, 2011), is reported as $350 \pm 60 \mathrm{ka}$ (Bachman 1980, 1984).

\section{Chronology of Berino Soil Formation}

The age of the parent material of the Berino paleosol is 90-50 ka. In many cases across the sand sheet, the Lower eolian sand and its Berino paleosol are buried by the Upper eolian sand (fig. 6). The age of the Upper eolian sand has been determined by 20 previous OSL dates from various localities on the sand sheet, with a range from $17.3 \pm 0.70$ to $5.82 \pm 0.41 \mathrm{ka}$ (Hall and Goble 2006, 2011; S. A. Hall and R. J. Goble, unpubl. data), with the rounded age extending from 18 to $5 \mathrm{ka}$. Thus, the time available for development of the Berino paleosol is represented by the period beginning after the deposition and stability of the Lower eolian sand and ending with the deposition and burial of the Berino by the Upper eolian sand. Consequently, the maximum period of time for Berino soil formation extends from 50 to $18 \mathrm{ka}$, a total of 32,000 yr that encompasses the late mid-Wisconsin and early late Wisconsin stages as well as the MIS late 3 and early 2 .

In the western area of the sand sheet, including the type section (locality 100), the Berino is presently not buried and may not have been buried in the past, except by twentieth-century coppice dunes. In this area, pedogenesis of the Berino could have extended from $50 \mathrm{ka}$ to present, although the wet climate resulting in the translocation of clay and leaching of carbonate may have ended after the late Wisconsin stage and MIS 2.
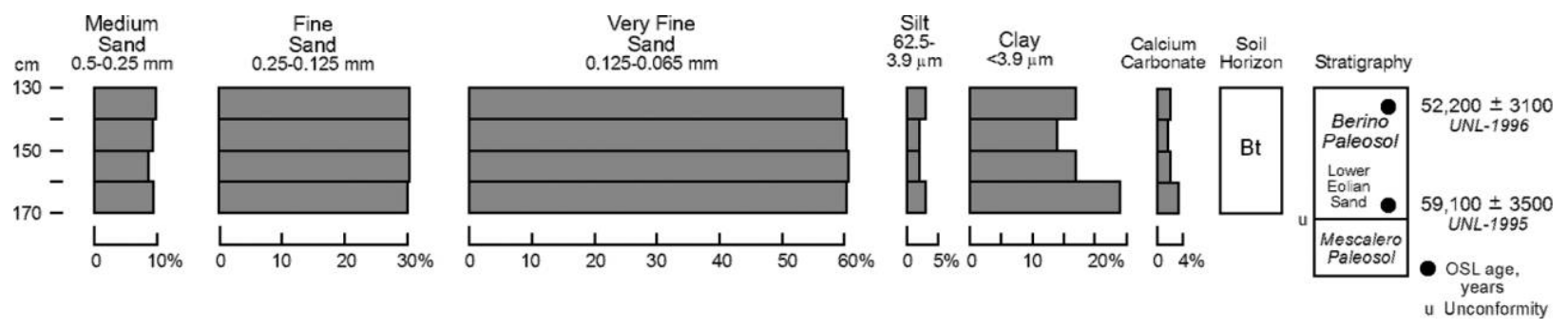

Figure 5. Sedimentology and chemistry of the Lower eolian sand and Berino paleosol, locality 300 (lat. $32^{\circ} 19^{\prime} 09.87^{\prime \prime} \mathrm{N}$, long. $103^{\circ} 49^{\prime} 23.32^{\prime \prime W}$; NW1/4 NW1/4 SW1/4 sec. 7, T. 23 S., R. 31 E., Eddy County; elevation, $1007 \mathrm{~m}[3304 \mathrm{ft}]$; Los Medaños, provisional edition, 7.5-min quadrangle, USGS 1985). The thin Lower eolian sand may be a result of erosion both before and after development of the Berino paleosol. The Bt horizon of the Berino completely engulfs the thin deposit of Lower eolian sand and forms an abrupt contact with the underlying stage III Mescalero paleosol. 


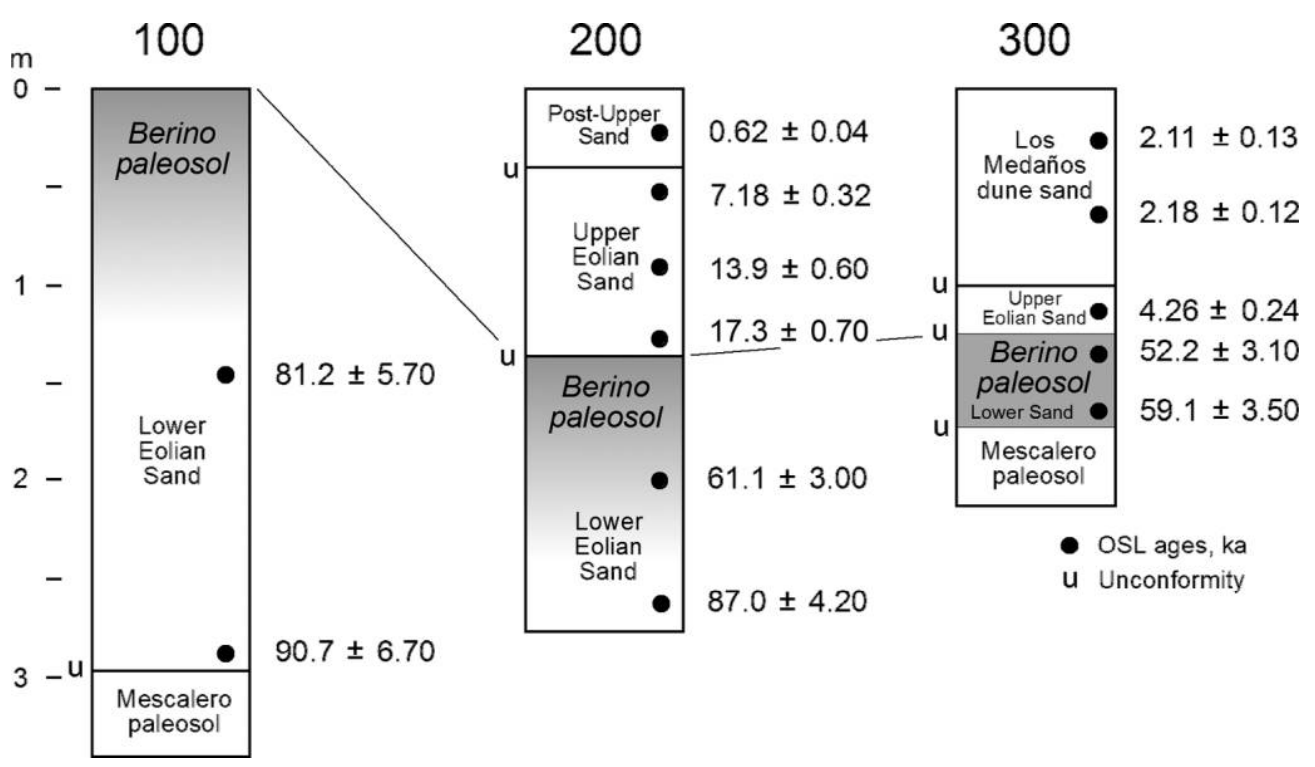

Figure 6. Correlation of the Berino paleosol across the Mescalero sand sheet, southeastern New Mexico. The optically stimulated luminescence ages from localities 100 and 200 are reported previously by Hall and Goble $(2006,2011)$. Locality 100, the type section of the Berino paleosol, is a relict soil, evidently never buried. The Berino paleosol is buried by younger eolian sand at localities 200 and 300 .

\section{Underlying Mescalero Paleosol}

In every case observed in the field, the Berino paleosol and its parent sand rest directly on the Mescalero paleosol. Bachman (1980) observed the same stratigraphy and considered the possibility that the "Berino soil" was the Bt horizon of the underlying Bk of the "Mescalero caliche" (now called the Mescalero paleosol), although Bachman also observed that the contact between the Berino and Mescalero paleosols is sharp. In a few rare localities where the Lower eolian sand is comparatively thick, such as the type section (locality 100), the Berino and Mescalero paleosols are separated by $2 \mathrm{~m}$ of eolian sand.

\section{Paleoenvironment of Berino Paleosol Development}

Vegetation and Vertebrate Faunal Records. The Berino paleosol formed in the wet, cool climate of the mid- and late Wisconsin glacial stage; the late Wisconsin incorporates the last glacial maximum. The regional vegetation and mammalian fauna of that time is moderately well known, providing a basis for reconstructing environmental conditions of the Mescalero sand sheet during the formation of the Berino paleosol.

The vegetation across the High Plains of Texas and New Mexico in the mid- and late Wisconsin was a sagebrush grassland (Hall and Valastro 1995;
Hall 2001, 2005). Plant macrofossils from woodrat middens also indicate the presence of big sagebrush (Artemisia tridentata) in the regional flora (Hall and Riskind 2010). Vertebrate fossils from area caves include the sagebrush vole (Lemmiscus curtatus) and Nutall's cottontail (Sylvilagus nuttallii), found in the sagebrush steppe (Harris 1970, 1989). Harris concluded that the late Wisconsin mammalian fauna of southeastern New Mexico has its best modern analogue in the present-day sagebrush steppe of southeastern Idaho.

The difference in present-day climate between southeastern New Mexico and southeastern Idaho may indicate the character of environmental conditions at the time the Berino paleosol formed during the Wisconsin glacial stage. Compared with southeastern New Mexico, the climate of southeastern Idaho is cooler by about $11^{\circ} \mathrm{C}\left(20^{\circ} \mathrm{F}\right)$ and has greater amounts of annual precipitation by about $15 \mathrm{~cm} \mathrm{(6} \mathrm{in;} \mathrm{although} \mathrm{variable} \mathrm{as} \mathrm{a} \mathrm{region),} \mathrm{with}$ $40 \%-70 \%$ of the rainfall in winter months (October-March). In southeastern New Mexico, 70\%$80 \%$ of the rainfall is in summer months (AprilSeptember), due to the influence of the Mexican monsoon. Southeastern Idaho also has greater humidity and considerably lower amounts of annual pan evaporation (table 2). It may not be accurate to literally apply the climatic attributes of Idaho directly to the Wisconsin time in New Mexico, but it is reasonable to generalize from the vegetation- 
Table 2. Comparative Climate Data from Southeastern New Mexico and Southeastern Idaho

\begin{tabular}{lcr}
\hline & SE New Mexico & SE Idaho \\
\hline Latitude $\left({ }^{\circ} \mathrm{N}\right)$ & $32-33$ & $42-44$ \\
Mean annual temperature $\left({ }^{\circ} \mathrm{C}\left[{ }^{\circ} \mathrm{F}\right]\right)$ & $4.4-10.0(40-50)$ \\
Mean annual precipitation $(\mathrm{cm}[\mathrm{in}])$ & $15.6-21.1(60-70)$ & $35.6-63.5(14-25)$ \\
Summer precipitation (Apr.-Sept.; \%) & $30.5-40.6(12-16)$ & $30-60$ \\
Winter precipitation (Oct.-Mar.; \%) & $70-80$ & $40-70$ \\
July-Aug. precipitation (\%) & $20-30$ & $10-20$ \\
Mean annual relative humidity (\%) & $30-40$ & $56-65$ \\
Mean annual pan evaporation (cm [in]) & $46-55$ & $101.6-139.7(40-55)$ \\
Mean annual total hours of sunshine & $254.0-279.4(100-110)$ & $2600-3000$ \\
\hline
\end{tabular}

Note. Data from various sources at the National Oceanic and Atmospheric Administration.

faunal data that the climate during the period of pedogenesis of the Berino paleosol was wetter and cooler and with higher humidity than at present.

Speleothems. Sequences of oxygen isotope ratios $\left(\delta^{18} \mathrm{O}\right)$ from stalagmite calcite at Fort Stanton Cave, New Mexico, and Cave of the Bells, Arizona, provide information on late Pleistocene precipitation in the Southwest (Asmeron et al. 2010; Wagner et al. 2010). Although the high-resolution sequences show a great deal of variability, the climate during the period of formation of the Berino paleosol was comparatively wetter and cooler than today. The $\delta^{18} \mathrm{O}$ data further indicate that most of the moisture was derived predominantly from the Pacific during the winter and less from the Gulf of Mexico during the summer monsoon, perhaps a consequence of a southward shift in the polar jet stream during the mid- and late Wisconsin. The speleothem oxygen isotope studies support the vegetation and vertebrate faunal records that indicate cool and wet conditions during the period of Berino soil formation.

\section{Discussion}

Thickness of Parent Sand. The parent material of the Berino paleosol is a fine-textured, massive quartz sand throughout the sand sheet. The thickness of the parent material is pivotal to what is observed in the field regarding the development of the Berino paleosol. Where the thickness of the Lower eolian sand is greater than $1 \mathrm{~m}$, the Bt horizon is fully developed with an underlying $\mathrm{C}$ horizon, such as localities 100 and 200. However, where the parent sand is generally less than $1 \mathrm{~m}$ thick, such as locality 300, the Bt has overwhelmed the sand and a C horizon is absent. In many areas of the sand sheet where the Lower eolian sand is thin, the Berino paleosol appears as a massive, homogenous, noncalcareous red sand resting on weathered caliche of the Mescalero paleosol.
Holocene Secondary Carbonate. Although the paleosol has no visible carbonate, generally does not react to dilute $\mathrm{HCl}$, and is regarded as noncalcareous, laboratory data show carbonate ranging from $0.9 \%$ to $1.9 \%$ in the Bt horizon at locality 100 , where the Berino is not buried. Where the paleosol is buried by younger sand, the carbonate content ranges from $1.3 \%$ to $3.5 \%$ (localities 200,300 ). The percentage of carbonate varies directly with the amount of clay in the Bt horizon (fig. 7). In other late Pleistocene paleosols, the Bk horizon commonly underlies the Bt horizon (Birkeland 1999). In the Berino paleosol, however, small amounts of carbonate are concentrated with the Bt clay, suggesting that the carbonate accumulated after Bt development. The carbonate in the clayey Bt horizon

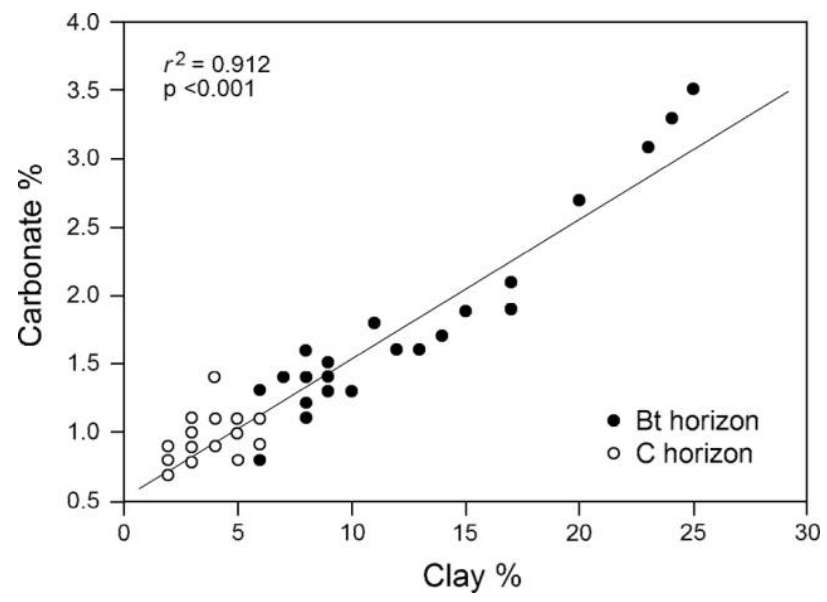

Figure 7. Carbonate percentages versus clay percentages in the $\mathrm{Bt}$ and $\mathrm{C}$ horizons of the Berino paleosol, localities 100, 200, and 300, Eddy County, New Mexico; 43 paired data points, some points overlap; linear regression analysis by SigmaPlot 12.0. The strong correlation of percentages of carbonate and clay supports the interpretation that the carbonate accumulated in the clayey Bt horizon during the Holocene after the formation of the Berino paleosol. 


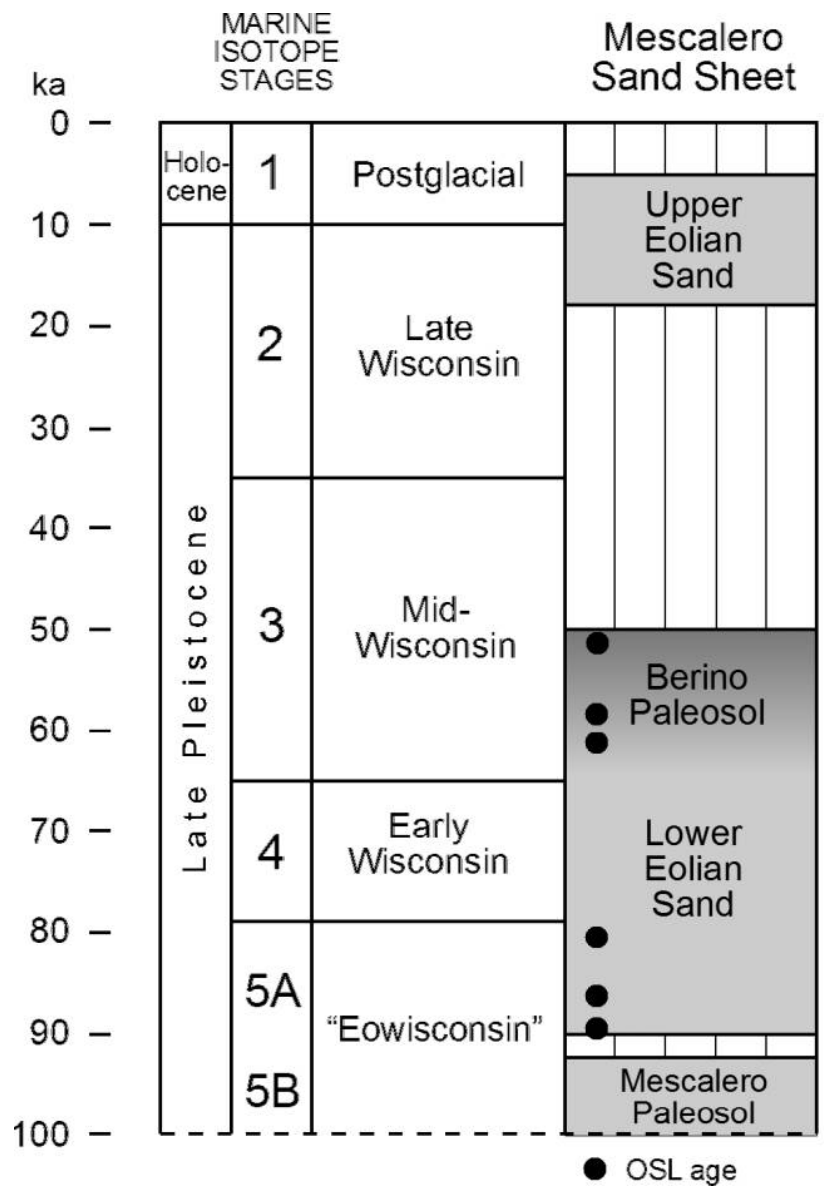

GEOMORPHIC PROCESSES

Deposition of Upper eolian sand 18 to $5 \mathrm{ka}$; yellowish red, fine-to-medium and fine-tovery fine quartz sand, massive; absence of buried soils; Bw horizon at top of sand; top eroded and BW absent in places

Pedogenesis of Berino soil 50 to $18 \mathrm{ka}$; some erosion of Lower eolian sand before and after Berino soil development

Deposition of Lower eolian sand 90 to $50 \mathrm{ka}$; red, fineto-medium quartz sand; massive; absence of soils except for Berino paleosol

Erosion of top of calcic Mescalero paleosol in most areas

Figure 8. Time-stratigraphy diagram of the Mescalero sand sheet with the Lower eolian sand containing the Berino paleosol. Twentieth-century coppice and parabolic dunes mantle the sand sheet but are not shown. The vertical-line pattern indicates an absence of eolian deposits and represents periods of nondeposition and erosion, sand sheet stability, and soil formation. The geochronology of the Upper eolian sand is based on 20 optically stimulated luminescence ages (Hall and Goble 2006, 2011; S. A. Hall and R. J. Goble, unpubl. data).

was probably transported downprofile during the Holocene, a phenomenon discussed by McFadden and Tinsley (1985).

Correlations of the Berino Paleosol. The OSL geochronology of stratigraphic sequences and paleosols from eolian sand sheets in the region is in its infancy. At this stage of research, two possible correlations of the Berino paleosol and its associated eolian sand occur on the High Plains of Texas and in the Tularosa Valley-Hueco Bolson of New Mexico and Texas. On the High Plains, the Blackwater Draw Formation is predominantly a very fine to fine sand and sandy silt of eolian origin, with as many as 11 buried soils (Holliday 1989; Gustavson 1996). Its age extends from $1.4 \mathrm{Ma}$ to $118 \mathrm{ka}$. The uppermost reddish brown 5YR hue Bt-Bk paleosol at the type section of the Blackwater Draw Formation is not directly dated but has been reported throughout the southern High Plains and may cor- respond to the Berino Bt paleosol (Holliday 2001). Near El Paso, Texas, a yellowish red 5YR hue Bt paleosol occurs in the Q2 eolian sand of the Bolson sand sheet with a single OSL age of $44.8 \pm 2.9 \mathrm{ka}$ (Hall et al. 2010). In many cases, the Q2 sand and red paleosol are buried by the younger Q3 eolian sand. The Q2 and Q3 eolian sands of the Bolson sand sheet correlate in general with the Lower and Upper eolian sands in the Mescalero sand sheet, respectively. Eventually, as further systematic OSL dating results are available, correlations of these eolian sequences should become clearer.

\section{Summary and Conclusions}

The Berino paleosol is the first case of late Quaternary argillic soil development in the American Southwest where both the period of time in abso- 
lute years and the paleoclimatic conditions of pedogenesis are known. The Berino paleosol formed during the late mid-Wisconsin and the early late Wisconsin and MIS late 3 and early 2 between 50 $\mathrm{ka}$ and $18 \mathrm{ka}$, the chronology determined by OSL dating (fig. 8). The climate during the period of Berino soil formation in southeastern New Mexico is estimated from late Pleistocene vegetation and vertebrate faunas and supported by oxygen isotope sequences from speleothems to have been $11^{\circ} \mathrm{C}\left(20^{\circ} \mathrm{F}\right)$ cooler, with $15 \mathrm{~cm}(6$ in) greater rainfall than today. If correct, the Berino argillic soil formed during a period of 32,000 yr under climatic conditions with an estimated mean annual precipitation of $51 \mathrm{~cm}$ (20 in) and mean annual temperature of $7^{\circ} \mathrm{C}\left(45^{\circ} \mathrm{F}\right)$.

The Berino paleosol is a red 2.5YR argillic $\mathrm{Bt}$ without calcic Btk or Bk horizons. The Bt horizon is $120 \mathrm{~cm}$ thick, with $25 \%$ clay and $0.36 \% \mathrm{Fe}$. It is classified as an Argid in the Aridisol soil order. The paleosol formed on the stable surface of the Lower eolian sand, the older of two main units of the Mescalero sand sheet. The Bt horizon clay is derived from atmospheric dust and not weathering of the eolian sand parent material. The paleosol is buried by younger eolian sand in the core of the Mescalero sand sheet. At the western margin of the sand sheet, however, the Berino is a relict soil, unburied today except by twentieth-century coppice dunes. Although the paleosol is noncalcic, small amounts of carbonate are present in the clayey ar- gillic horizon, a result of accumulation during the Holocene. A similar red paleosol occurs at the top of the Blackwater Draw Formation on the High Plains and in the Q2 eolian sand unit of the Bolson sand sheet near El Paso. It has been possible to determine the geochronology and paleoenvironment of the Berino paleosol because of high-resolution OSL dating of sand sheet stratigraphy. This methodology can be applied universally to other sand sheets and sequences of deposits and associated paleosols.

\section{A C K N O W L E G M E N T S}

We thank G. MacDonell and the Carlsbad Field Office of the Bureau of Land Management for a small grant to support these field and laboratory studies. We thank D. Boggess and Lone Mountain Archaeological Services, Albuquerque; Intrepid Potash-NM, Carlsbad; R. Wiseman and R. DelloRusso, Office of Archaeological Studies, Museum of New Mexico, Department of Cultural Affairs, Santa Fe; and New Mexico Department of Transportation, Santa Fe, for their support. We thank W. Johnson and L. Nordt for helpful suggestions with the manuscript. We extend a special acknowledgement to the late G. O. Bachman, colleague and extraordinary field geologist, who inspected the same geology and, 30 years ago, pointed the way.

\section{R E F E R E N C E S C I T E D}

Adamiec, G., and Aitken, M. 1998. Dose-rate conversion factors: update. Anc. TL 16:37-50.

Aitken, M. J. 1998. Introduction to optical dating: the dating of Quaternary sediments by the use of photonstimulated luminescence. Oxford, Oxford University Press, $267 \mathrm{p}$.

Asmerom, Y.; Polyak, V. J.; and Burns, S. J. 2010. Variable winter moisture in the southwestern United States linked to rapid glacial climate shifts. Nat. Geosci. 3: 114-117.

Bachman, G. O. 1976. Cenozoic deposits of southeastern New Mexico and an outline of the history of evaporate dissolution. J. Res. U.S. Geol. Surv. 4:135-149.

- 1980. Regional geology and Cenozoic history of Pecos region, southeastern New Mexico. U.S. Geol. Surv. Open-File Rep. 80-1099, 120 p.

- 1981. Geology of Nash Draw, Eddy County, New Mexico. U.S. Geol. Surv. Open-File Rep. 81-31, 12 p.

- 1984. Regional geology of Ochoan evaporates, northern part of Delaware Basin. N. M. Bur. Mines Min. Resour., Circ. 184, 22 p.

Bailey, R. M., and Arnold, L. J. 2006. Statistical modeling of single grain quartz De distributions and an assess- ment of procedures for estimating burial dose. Quat. Sci. Rev. 25:2475-2502.

Birkeland, P. W. 1999. Soils and geomorphology. 3rd ed. New York, Oxford University Press, 430 p.

Bretz, J. H., and Horberg, L. 1949. Caliche in southeastern New Mexico. J. Geol. 57:491-511.

Bulloch, H. E., Jr., and Neher, R. E. 1980. Soil survey of Dona Ana County area, New Mexico. Washington, DC, USDA Soil Conservation Service, 177 p.

Chugg, J. C.; Anderson, G. W.; King, D. L.; and Jones, L. V. H. 1971. Soil survey of Eddy area, New Mexico. Washington, DC, USDA Soil Conservation Service, 82 p.

Derr, P. S. 1981. Soil survey of Otero area, New Mexico. Washington, DC, USDA Soil Conservation Service, $244 \mathrm{p}$.

Folk, R. L. 1968. Petrology of sedimentary rocks. Austin, TX, Hemphill's, 170 p.

Galbraith, R. F.; Roberts, R. G.; Laslett, G. M.; Yoshida, H.; and Olley, J. M. 1999. Optical dating of single and multiple grains of quartz from Jinmium Rock Shelter, northern Australia. I. Experimental design and statistical models. Archaeometry 41:339-364. 
Gile, L. H.; Hawley, J. W.; and Grossman, R. B. 1981. Soils and geomorphology in the Basin and Range area of southern New Mexico: guidebook to the Desert Project. N. M. Bur. Mines Min. Resour., Mem. 39, 222 p.

Gustavson, T. G. 1996. Fluvial and eolian depositional systems, paleosols, and paleoclimate of the upper Cenozoic Ogallala and Blackwater Draw formations, southern High Plains, Texas and New Mexico. Austin, University of Texas, Bur. Econ. Geol., Rep. Investig. $239,62 \mathrm{p}$.

Hall, S. A. 2001. Geochronology and paleoenvironments of the glacial-age Tahoka Formation, Texas and New Mexico. N. M. Geol. 23:71-77.

- 2002. Field guide to the geoarchaeology of the Mescalero Sands, southeastern New Mexico. Santa Fe, NM, Bureau of Land Management and Historical Preservation Division, $55 \mathrm{p}$.

. 2005. Ice Age vegetation and flora of New Mexico. In Lucas, S. G.; Morgan, G. S.; and Zeigler, K. E., eds. New Mexico's ice ages. Bull. N. M. Mus. Nat. Hist. Sci. 28:171-183.

Hall, S. A., and Goble, R. J. 2006. Geomorphology, stratigraphy, and luminescence age of the Mescalero Sands, southeastern New Mexico. In Land, L.; Lueth, V. W.; Raatz, W.; Boston, P.; and Love, D. L., eds. Caves and karst of southeastern New Mexico. Guideb. N. M. Geol. Soc. 57:297-310.

- 2008. Archaeological geology of the Mescalero Sands, southeastern New Mexico. Plains Anthropol. 53:279-290.

-2011. New optical age of the Mescalero sand sheet, southeastern New Mexico. N. M. Geol. 33:9-16.

Hall, S. A.; Miller, M. R.; and Goble, R. J. 2010. Geochronology of the Bolson sand sheet, New Mexico and Texas, and its archaeological significance. Geol. Soc. Am. Bull. 122:1950-1967.

Hall, S. A., and Riskind, D. H. 2010. Palynology, radiocarbon dating, and woodrat middens: new applications at Hueco Tanks, Trans-Pecos Texas, USA. J. Arid Environ. 74:725-730.

Hall, S. A., and Valastro, S., Jr. 1995. Grassland vegetation in the southern Great Plains during the last glacial maximum. Quat. Res. 44:237-245.

Harris, A. H. 1970. The Dry Cave mammalian fauna and late pluvial conditions in southeastern New Mexico. Tex. J. Sci. 22:3-27.

-1989. The New Mexican Late Wisconsin: east versus west. Natl. Geogr. Res. 5:205-217.

Hendrickson, G. E., and Jones, R. S. 1952. Geology and ground-water resources of Eddy County, New Mexico. N. M. Bur. Mines Min. Resour., Groundw. Rep. 3, 169 p.

Holliday, V. T. 1989. The Blackwater Draw Formation (Quaternary): a 1.4-plus-m.y. record of eolian sedimentation and soil formation on the southern High Plains. Geol. Soc. Am. Bull. 101:1598-1607.

- 2001. Stratigraphy and geochronology of upper Quaternary eolian sand on the southern High Plains of Texas and New Mexico, United States. Geol. Soc. Am. Bull. 113:88-108.
Jaco, H. B. 1971. Soil survey of El Paso County, Texas. Washington, DC, USDA Soil Conservation Service, 60 $\mathrm{p}$.

Kelley, V. C. 1971. Geology of the Pecos country, southeastern New Mexico. N. M. Bur. Mines Min. Resour., Mem. 24, 78 p.

McFadden, L. E., and Tinsley, J. C. 1985. Rate and depth of pedogenic-carbonate accumulation in soils: formulation and testing of a compartment model. In Weide, D. L., ed. Soils and Quaternary geology of the southwestern United States. Geol. Soc. Am. Spec. Pap. 203:23-41.

Munsell Color. 2009. Munsell soil-color charts. Grand Rapids, MI, Munsell Color, 13 pl.

Murray, A. S., and Wintle, A. G. 2000. Luminescence dating of quartz using an improved single-aliquot regenerative-dose protocol. Radiat. Meas. 32:57-73.

- 2003. The single aliquot regenerative dose protocol: potential for improvements in reliability. Radiat. Meas. 37:377-381.

Neher, R. E., and Bailey, O. F. 1976. Soil survey of White Sands missile range, New Mexico. Washington, DC, USDA Soil Conservation Service, $64 \mathrm{p}$.

Nicholson, A., Jr., and Clebsch, A., Jr. 1961. Geology and ground-water conditions in southern Lea County, New Mexico. N. M. Bur. Mines Min. Resour., Groundw. Rep. 6, 123 p.

North American Commission on Stratigraphic Nomenclature. 2005. North American stratigraphic code. Am. Assoc. Petrol. Geol. Bull. 89:1547-1591.

Peterson, R. S., and Boyd, C. S. 1998. Ecology and management of sand shinnery communities: a literature review. Washington, DC, USDA Forest Service, Gen. Tech. Rep. RMRS-GTR-16, 44 p.

Prescott, J. R., and Hutton, J. T. 1994. Cosmic ray contributions to dose rates for luminescence and ESR dating: large depths and long-term time variations. Radiat. Meas. 23:497-500.

Reheis, M. C. 2006. A 16-year record of eolian dust in southern Nevada and California, USA: controls on dust generation and accumulation. J. Arid Environ. 67: 487-520.

Richmond, G. M., and Fullerton, D. S. 1986. Introduction to Quaternary glaciations in the United States of America. Quat. Sci. Rev. 5:3-10.

Rodnight, H. 2008. How many equivalent dose values are needed to obtain a reproducible distribution? Anc. TL 26:3-9.

Ruhe, R. V. 1965. Quaternary paleopedology. In Wright, H. E., Jr., and Frey, D. G., eds. The Quaternary of the United States. Princeton, NJ, Princeton University Press, p. 755-764.

Soil Survey Staff. 1994. Keys to soil taxonomy. 6th ed. Washington, DC, USDA Soil Conservation Service, 306 p.

Stout, J. E., and Lee, J. A. 2003. Indirect evidence of wind erosion trends on the southern High Plains of North America. J. Arid Environ. 55:43-61.

Turner, M. T.; Cox, D. N.; Mickelson, B. C.; Roath, A. J.; and Wilson, C. D. 1974. Soil survey of Lea County, 
New Mexico. Washington, DC, USDA Soil Conservation Service, $89 \mathrm{p}$.

Wagner, J. D. M.; Cole, J. E.; Beck, J. W.; Patchett, P. J.; Henderson, G. M.; and Barnett, H. R. 2010. Moisture variability in the southwestern United States linked to abrupt glacial climate change. Nat. Geosci. 3:110113.
Weide, D. L., ed. 1985. Soils and Quaternary geology of the southwestern United States. Geol. Soc. Am. Spec. Pap. 203, 150 p.

Wintle, A. G., and Murray, A. S. 2006. A review of quartz optically stimulated luminescence characteristics and their relevance in single-aliquot regeneration dating protocols. Radiat. Meas. 41:369-391. 